\title{
Methionine Sulfoxide Reductases Contribute to Anaerobic Fermentative Metabolism in Bacillus cereus
}

\author{
Catherine Duport ${ }^{1, *} \mathbb{B}$, Jean-Paul Madeira ${ }^{1}$, Mahsa Farjad ${ }^{1}$, Béatrice Alpha-Bazin ${ }^{2} \mathbb{C}$ and Jean Armengaud ${ }^{2} \mathbb{B}$ \\ 1 Département de Biologie, Avignon Université, INRAE, UMR SQPOV, F-84914 Avignon, France; \\ jean-paul.madeira@inrae.fr (J.-P.M.); mahsa.farjad@inrae.fr (M.F.) \\ 2 Département Médicaments et Technologies pour la Santé (DMTS), Université Paris-Saclay, CEA, INRAE, SPI, \\ F-30200 Bagnols-sur-Cèze, France; beatrice.alpha-bazin@cea.fr (B.A.-B.); jean.armengaud@cea.fr (J.A.) \\ * Correspondence: catherine.duport@univ-avignon.fr; Tel.: +33-432-722-507
}

check for updates

Citation: Duport, C.; Madeira, J.-P.; Farjad, M.; Alpha-Bazin, B.; Armengaud, J. Methionine Sulfoxide Reductases Contribute to Anaerobic Fermentative Metabolism in Bacillus cereus. Antioxidants 2021, 10, 819. https://doi.org/10.3390/ antiox10050819

Academic Editors: Luis M. Mateos and Michal Letek

Received: 2 April 2021

Accepted: 17 May 2021

Published: 20 May 2021

Publisher's Note: MDPI stays neutral with regard to jurisdictional claims in published maps and institutional affiliations.

Copyright: (c) 2021 by the authors. Licensee MDPI, Basel, Switzerland. This article is an open access article distributed under the terms and conditions of the Creative Commons Attribution (CC BY) license (https:/ / creativecommons.org/licenses/by/ $4.0 /)$.

\begin{abstract}
Reversible oxidation of methionine to methionine sulfoxide $(\mathrm{Met}(\mathrm{O}))$ is a common posttranslational modification occurring on proteins in all organisms under oxic conditions. Protein-bound $\operatorname{Met}(\mathrm{O})$ is reduced by methionine sulfoxide reductases, which thus play a significant antioxidant role. The facultative anaerobe Bacillus cereus produces two methionine sulfoxide reductases: MsrA and MsrAB. MsrAB has been shown to play a crucial physiological role under oxic conditions, but little is known about the role of MsrA. Here, we examined the antioxidant role of both MsrAB and MrsA under fermentative anoxic conditions, which are generally reported to elicit little endogenous oxidant stress. We created single- and double-mutant $\triangle m s r$ strains. Compared to the wild-type and $\triangle m s r A B$ mutant, single- $(\triangle m s r A)$ and double- $(\triangle m s r A \Delta m s r A B)$ mutants accumulated higher levels of Met $(\mathrm{O})$ proteins, and their cellular and extracellular $\operatorname{Met}(\mathrm{O})$ proteomes were altered. The growth capacity and motility of mutant strains was limited, and their energy metabolism was altered. MsrA therefore appears to play a major physiological role compared to MsrAB, placing methionine sulfoxides at the center of the B. cereus antioxidant system under anoxic fermentative conditions.
\end{abstract}

Keywords: methionine oxidation; methionine sulfoxide reductase; anaerobiosis; Bacillus cereus

\section{Introduction}

Bacillus cereus is a notorious food-borne gram-positive pathogen that can adapt to various oxygenation conditions encountered in the environment, in foods and in the human intestine [1]. Under anaerobiosis and in the absence of a final electron acceptor such as nitrate, $B$. cereus sustains its growth by producing ATP through mixed acid fermentation. This process generates lactate as the main metabolite, along with smaller amounts of acetate, formate, succinate, and ethanol [2-4]. Traditionally, fermentative conditions are not considered to produce reactive oxygen species (ROS), due to the decreased oxidative phosphorylation taking place. However, experimental evidence suggests that an antioxidant response nevertheless occurs in fermenting $B$. cereus cells $[5,6]$. This response may be due to $B$. cereus undergoing transient secondary oxidative stress upon exposure to anaerobic fermentative conditions, through nitric oxide (NO) production [7], as a result of the action of nitric oxide synthase on arginine [8-10].

The sulfur-containing methionine residues in proteins are especially sensitive to ROS-mediated oxidation [11]. Oxidation of methionine results in two diastereomic forms of methionine sulfoxide $(\operatorname{Met}(\mathrm{O}))$ : methionine-S-sulfoxide (Met-S-O) and methionine-Rsulfoxide (Met-R-O). The reaction is reversible thanks to the action of methionine sulfoxide reductase (Msr) [12]. Four types of Msr have been identified that reduce Met(O) residues to their functional form [13]. The main types are the thiol-oxidoreductases MsrA and $\mathrm{MsrB}$, which react specifically with diastereomers displaying the S- and R-configurations at the sulfur atom, respectively $[14,15]$. The third and fourth types of Msr belong to the molybdenum-containing enzyme families. The third type of Msr, periplasmic methionine 
sulfoxide reductase (MsrP), is present in most gram-negative bacteria and is a member of the sulfite oxidase family. MsrP is not a stereospecific protein-MetO reductase [16]. The fourth type of Msr belongs to the dimethyl sulfoxide (DMSO) reductase family. One example is the periplasmic Rhodobacter sphaeroides DorA DMSO reductase, which reduces DMSO and both free and protein-bound Met-S-O [13]. The primary role of the first three types of Msr is to regulate the $\operatorname{Met}(\mathrm{O})$ level in proteins; they reduce $\operatorname{Met}(\mathrm{O})$ residues more efficiently in unfolded proteins than in folded proteins [17]. The role of DorA-like enzymes in protecting proteins against oxidation remains to be validated in vivo [16]. Cyclic Msrdependent methionine oxidation/reduction was proposed to be an important antioxidant defense mechanism in both bacteria and eukaryotic cells, playing a scavenging role for cellular ROS under normal and stressed conditions [11,17-20]. Msr can also regulate protein function by modulating specific $\operatorname{Met}(\mathrm{O})$ residues involved in protein activation or inactivation [21]. Consequently, these enzymes are implicated in a variety of biological processes, including redox signaling, cellular metabolism, and virulence. Although Msr and other antioxidants have been identified in both facultative and strict anaerobes [22,23], their role in cellular processes under anoxic conditions remains largely uncharacterized. The few studies available report results for yeast, where MsrA and MsrB were reported not to contribute to the ROS-regulated lifespan under strict anoxic conditions [24], and for the strict anaerobic bacterium Clostridium oremlandii, where high activity levels of the selenoprotein MsrA were detected [25]. However, no physiological role has yet been proposed for these enzymes in anoxic conditions.

Whole-genome sequence analysis of B. cereus ATCC 14579 revealed two genes encoding Msr. The first of these genes, $m s r A B$, encodes a bifunctional cytoplasmic MsrAB enzyme, and is probably the result of gene fusion [26]. Our previous results indicated that MsrAB plays a key role in redox homeostasis in B. cereus under aerobic respiratory conditions, and regulates exotoxin secretion [27]. The role of MsrA has not been investigated to date. For this study, we generated single and double mutants of $m s r A$ and $m s r A B$ to investigate the antioxidant role of Msr proteins, under anaerobic fermentative growth conditions, using a proteomics approach. The results suggest that the repair of $\operatorname{Met}(\mathrm{O})$-containing proteins contributes significantly to anaerobic fermentative growth of $B$. cereus, and demonstrate clearly distinct in vivo contributions from MsrA and MsrAB to the reduction of cellular protein-bound $\operatorname{Met}(\mathrm{O})$.

\section{Materials and Methods}

\subsection{Strains, Media, and Growth Conditions}

Wild-type B. cereus ATCC 14579 without its pBClin15 plasmid [28], the single mutants $\triangle m s r A, \triangle m s r A B$ [27], and the $\triangle m s r A \triangle m s r A B$ double mutant strains were grown either in Luria broth (LB) or MOD medium supplemented with $30 \mathrm{mM}$ glucose (MODG) as the carbon source, as previously described [3]. Controlled anaerobic batch cultures were performed at $37^{\circ} \mathrm{C}$ in $2 \mathrm{~L}$ bioreactors (Discovery 100, Iceltech, France) containing $1.5 \mathrm{~L}$ MODG medium. $\mathrm{pH}$ was maintained at 7.2 by automatic addition of $5 \mathrm{M} \mathrm{KOH}$, and constant shaking at $300 \mathrm{rpm}$. Anaerobiosis $\left(\mathrm{pO}_{2}=0 \%\right)$ was obtained by continuously flushing the medium with pure nitrogen gas $(20 \mathrm{~mL} / \mathrm{h})$ that had been passed through a Hungate column. The inoculum was a $100-\mathrm{mL}$ sample of an exponential anaerobic culture ( $250 \mathrm{~mL}$ Erlenmeyer flasks fitted with open-top caps and rubber septa) harvested by centrifugation, washed twice and diluted in fresh MODG medium to obtain an initial optical density at $600 \mathrm{~nm}$ of 0.02 . Three biological replicates were analyzed for each strain.

\subsection{Analytical Procedures}

The growth of B. cereus WT and mutant strains was monitored spectrophotometrically at $600 \mathrm{~nm}$. The maximal specific growth rate $\left(\mu_{\max }\right)$ was determined by applying the modified Gompertz equation [29]. Culture samples $(250 \mathrm{~mL})$ were harvested anaerobically during the early exponential (EE, $\mu=\mu_{\max }$ ), late exponential (LE), and stationary (S) growth phases and treated in an anaerobic chamber. Cells and culture supernatants were separated 
by centrifugation $\left(10,000 \times g, 10 \mathrm{~min}, 4^{\circ} \mathrm{C}\right)$. Cells were suspended in PBS buffer, and stored at $-20^{\circ} \mathrm{C}$. Supernatants were filtered as previously described [6], aliquoted in small volumes, and stored frozen at $-20^{\circ} \mathrm{C}$ until analysis.

Glucose, lactate, ethanol, formate, acetate, and succinate concentrations were determined in filtered supernatants using Enzytec Fluid kits (R-Biofarm, Saint-Didier-au-Mont$\mathrm{d}^{\prime} \mathrm{Or}$, France) according to the manufacturer's protocol.

Cellular and extracellular proteins were extracted from cell pellets and filtered supernatant samples as previously described $[27,30]$. All manipulations were performed in an anaerobic chamber to avoid artefactual oxidation.

\subsection{Relative Quantification of msrA and msrAB Gene Expression}

Real time quantitative RT-PCR experiments were performed as described previously [27]. Briefly, real-time RT-PCR was performed using the iScript ${ }^{\mathrm{TM}}$ One-Step RT-PCR kit with SYBR ${ }^{\circledR}$ Green following the manufacturer's protocol (Biorad, Marne-La-Coquette, France), with $10 \mathrm{ng}$ of total RNA as a template. Total RNA was extracted from B. cereus cells at EE, LE and S growth phases by using TRI Reagent RNA extraction solution as recommended by the manufacturer (Ambion, Thermo Fischer Scientific, Illkirch, France). The Agilent 2100 Bioanalyzer system was used to characterize and quantify total RNA. The mRNA level changes for each gene were normalized to the RNA level for the ssu gene, encoding $16 \mathrm{~S}$ RNA, and quantified by the $2-\Delta \Delta C T$ method. The specific primer pairs used in these experiments were: $5^{\prime}$-TTCTGGTACACAGGTGGTC- $3^{\prime}$ and $5^{\prime}$-AAAGCGTCCACTCTGCTCAA$3^{\prime}$ for $m s r A B$ (BC_5436, NC_004722.1); 5'-TCCAACTGATGATGGCGGAC and 5'-TCAC GCCCAGATTCTTTTTGC-3' for msrA (BC_1774, NC_004722.1). Data from two technical replicates, for each of the three biological replicates, were used to conduct statistical analysis.

\subsection{Construction of msrA Mutant Strains}

The $m s r A$ gene (BC 1774) was disrupted in B. cereus ATCC 14579 by allelic exchange with a spectinomycin resistance cassette $\left(\mathrm{Sp}^{\mathrm{R}}\right.$, [31]), and in the B. cereus $\triangle m s r A B$ strain by exchange with a kanamycin resistance cassette $\left(\mathrm{Km}^{\mathrm{R}}\right)$, as described by Arnaud et al. ([32]). Briefly, a 949-bp DNA fragment encompassing the $m s r A$ gene was obtained by PCR using the following primers: 5'GAATTCGCTTAGGTGAAGTAGAAGACATTG-3' (with an EcoRI site at the $5^{\prime}$ end) and $5^{\prime}$ AGATCTGTATATAAGATGGACAATTAAACAAAG-3' (with a BglII site at the $5^{\prime}$ end). The PCR product was cloned into pCRXL-TOPO (Invitrogen, Thermo Fischer Scientific, Illkirch, France), and the recombinant plasmid (pCRXL-TOPO:msrA) was digested with XmnI. The 1.5-kb Sp${ }^{R}$ cassette was isolated from pDIA [2] by digestion with SmaI, and the $1.5-\mathrm{kb} \mathrm{Km}^{\mathrm{R}}$ cassette was isolated from pDG789 [33] by digestion with SmaI and StuI. The resistance cassettes were ligated into the XmnI-digested pCRXL-TOPO:msrA vector. The resulting plasmids were subsequently digested with EcoRI and BglII to extract the msrA::Spr ${ }^{R}$ and $m s r A:: \mathrm{Km}^{\mathrm{R}}$ fragments. These fragments were cloned into pMAD precut with the same restriction enzymes. The pMAD-msrA::Spr ${ }^{\mathrm{R}}$ plasmid was introduced into $B$. cereus WT and the pMAD-msr $A:: \mathrm{Km}^{\mathrm{R}}$ was introduced into the $\triangle m s r A B$ mutant by electroporation. The $m s r A$ gene was deleted in both strains by a double crossover event. Chromosomal allele exchanges were confirmed by PCR with oligonucleotide primers located upstream and downstream of the DNA regions used for allelic exchange. For some experiments, the $m s r A$ gene was complemented in trans by cutting the pCRXL-TOPO: $m s r A$ plasmid with EcoRI and BglII and ligating the product to similarly digested pHT304 [34]. The integrity of the insert in the recombinant vector was verified by sequencing, and the vector was then used to transform the B. cereus mutant strains.

\subsection{Proteomics Analysis}

Cellular and extracellular proteins from the 36 samples ( 3 biological replicates $\times 3$ time-points $\times 4$ strains) of WT, $\triangle m s r A, \triangle m s r A B$ and $\triangle m s r A \Delta m s r A B$ strains were subjected to a short electrophoretic migration (about 3 min) on NuPAGE 4-12\% Bis-Tris gels (In- 
vitrogen, Thermo Fischer Scientific, Illkirch, France) using NuPAGE MES supplemented with NuPAGE antioxidant as running buffer [35]. Proteins were then submitted to in gel proteolysis with sequencing-grade trypsin (Roche, Sigma Aldrich, Saint Quentin Fallavier, France) according to the ProteaseMAX protocol (Promega, Madison, WI, USA) [36,37]. Samples were analyzed by Liquid Chromatography with Tandem Mass spectrometry (nanoLC-MS/MS) using an LTQ-Orbitrap XL hybrid mass spectrometer (Thermo Fisher Scientific, Illkirch, France) coupled to an Ultimate 3000 nRSLC system (Dionex, Thermo Fisher Scientific, Illkirch, France). NanoLC-MS/MS analysis was performed as previously described $[27,38]$. Briefly, peptides were resolved on a Dionex nanoscale Acclaim Pepmap100 C18 capillary column ( $3 \mu \mathrm{m}$ bead size, $100 \AA$ A pore size, $75 \mu \mathrm{m}$ i.d. $\times 15 \mathrm{~cm})$ at a flow rate of $0.3 \mu \mathrm{L} / \mathrm{min}$ over $90 \mathrm{~min}$, applying a gradient from 5 to $60 \%$ solvent $\mathrm{B}(0.01 \%$ $\mathrm{HCOOH} / 100 \% \mathrm{CH}_{3} \mathrm{CN}$ ) and, over $180 \mathrm{~min}$, applying a gradient from 5 to $50 \%$ solvent $\mathrm{B}$. Solvent A was $0.01 \% \mathrm{HCOOH} / 100 \% \mathrm{H}_{2} \mathrm{O}$. Tryptic MS/MS spectra were searched against an in-house B. cereus ATCC 14579 database using the MASCOT Daemon search engine with the following parameters: $5 \mathrm{ppm}$ peptide tolerance, $0.5 \mathrm{Da}$ fragment ion tolerance, $2^{+}$or $3^{+}$ peptide charge, a maximum of two missed cleavages, carbamidomethylation of cysteine $(+57.0215)$ as fixed modification, and oxidation of Met $(+15.5949)$ as a variable modification. Only peptides identified with a $p$-value $<0.05$ in homology threshold mode, and proteins identified by at least two distinct peptides, were retained upon parsing with IRMa software v1.3.1 [39]. The false positive rate determined from the corresponding decoy database was estimated to be less than $1 \%$.

Changes in protein abundance and Met(O)peptide levels between WT and mutant strains at the different time-points were analyzed using the Bioconductor DEP package (version 1.12.0), and $\mathrm{R}$ version 4.0.2 [40]. Met(O)peptides were first filtered to ensure two valid identifications in at least two biological replicates. Relative Met(O)peptide abundance levels were calculated based on the $\operatorname{Met}(\mathrm{O})$ spectral count normalized with respect to the total number of spectra. Missing values were imputed using random draws from a Gaussian distribution centered around a minimal value. Relative protein abundances were calculated based on spectral counts after correction and normalization by variance stabilizing (vsn), using the Limma package. Significant changes were selected where the adjusted $p$-value was less than 0.05 and the $\mid$ fold-change $\mid \geq 1.5$.

Mass spectrometry associated proteomics data have been deposited to the ProteomeXchange Consortium via the PRIDE partner repository under dataset identifiers PXD024888 for the cellular proteome of B. cereus ATCC 14579, PXD024927 for the cellular proteome of the $\triangle m s r A B$ mutant, PXD024850 for the cellular proteome of $\triangle m s r A$ mutant, PXD024849 for the cellular proteome of $\triangle m s r A B \triangle m s r A$ mutant, PXD024702 for the exoproteome of $B$. cereus ATCC 14579, PXD024714 for the exoproteome of $\triangle m s r A B$ mutant, PXD024847 for the exoproteome of $\triangle m s r A$ mutant, and PXD024848 for the exoproteome of the $\triangle m s r A B \triangle m s r A$ mutant.

\subsection{Motility Assays}

The B. cereus WT and mutant strains were grown overnight and surface-spotted $(5 \mu \mathrm{L})$ in the center of Tryptone- $\mathrm{NaCl}$ plates ( $1 \%$ tryptone, $0.5 \% \mathrm{NaCl}$ ) semi-solidified with $0.25 \%$ and $0.7 \%$ agar to assess swimming and swarming motility, respectively [41]. Motility diameters (indicative of migration of the bacteria from the center to the periphery of the plate) were measured after $72 \mathrm{~h}$ incubation at $37^{\circ} \mathrm{C}$ in AnaeroPack ${ }^{\mathrm{TM}}$ Jars (Thermo Fisher, Scientific, Illkirch, France). Biological triplicates were performed for all experiments.

\subsection{Statistical Analyses}

Data from three biological replicates were pooled for statistical analyses. Comparisons among multiple groups were analyzed by analysis of variance (ANOVA) followed by Tukey's post hoc analysis (qRT-PCR and $\operatorname{Met}(\mathrm{O})$ quantification experiments). Changes in motility and metabolite production were evaluated using the Student's t-test. Statistical 
analyses were performed using XLSTAT software (version 2021.1, Addinsoft, Paris, France). $p$-values $\leq 0.05$ were considered significant.

\section{Results}

\subsection{Expression Patterns for B. cereus $m s r A$ and $m s r A B$ RNA and Proteins under Fermentative} Anaerobic Conditions

In silico analysis of the $B$. cereus ATCC 14579 genome identified two genes encoding methionine sulfoxide reductase. The first gene, msrAB (BC_5436), has been described elsewhere and encodes a cytoplasmic MsrAB protein [27]. The second gene (BC_1774) was annotated as $m s r A$. It encodes a predicted cytoplasmic MsrA protein consisting of 178 amino acids, with a theoretical molecular mass of $20475 \mathrm{Da}$. This protein contains an MsrA domain that shares $64 \%$ sequence identity to the MsrA domain of the bifunctional MsrAB protein.

We compared the mRNA levels of $m s r A$ and $m s r A B$ during the EE, LE, and $\mathrm{S}$ growth phases under anoxic conditions. Figure 1 shows that maximum mRNA expression levels for $m s r A$ and $m s r A B$ were reached during the LE growth phase and, in contrast to $m s r A B$, the mRNA level for $m s r A$ was higher during the EE growth phase than during the $S$ growth phase $(p<0.05)$. The kinetics of $m s r A B$ expression under anaerobiosis was distinct from that described previously under aerobiosis [27]. Both $m s r A$ and $m s r A B$ mRNA levels increased under aerobiosis during active growth, and remained high during the stationary growth phase (Figure S1). This expression profile suggests that the growth-phase-dependent expression of $m s r$ genes is influenced by oxygenation conditions.

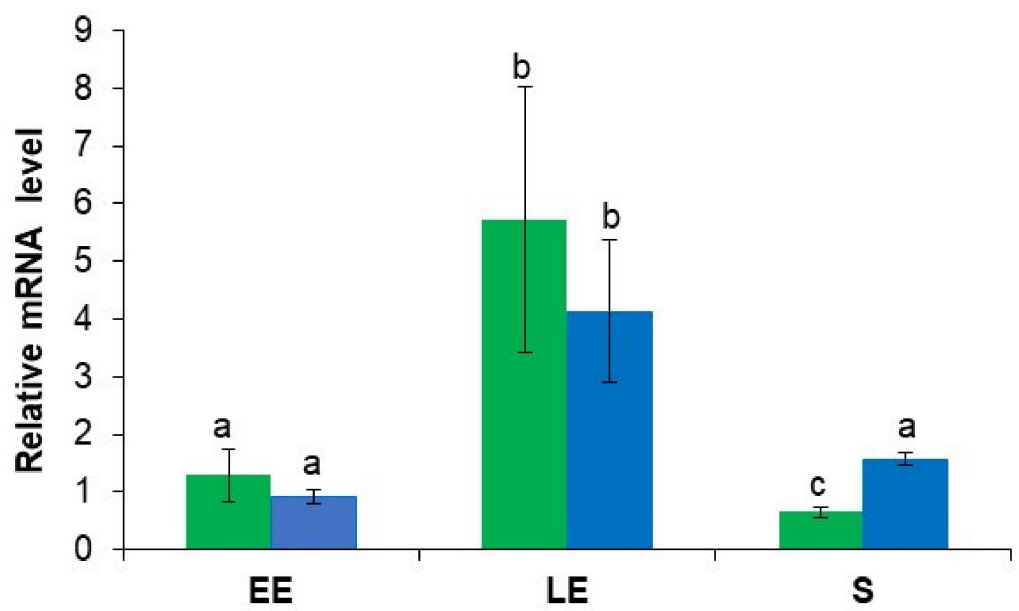

Figure 1. Analysis of $m s r A$ and $m s r A B$ gene expression in B. cereus ATCC 14579 cells grown under anaerobiosis. mRNA levels of $m s r A$ (green) and $m s r A B$ (blue) were determined at the early exponential (EE), late exponential (LE) and stationary (S) growth phases by quantitative real-time RT-PCR and normalized to ssu mRNA levels. Samples were harvested as indicated in Figure 2. Data correspond to the mean \pm SD of six samples (two technical replicates $x$ three biological replicates). Data denoted by a common letter are not significantly different. Data denoted by different letters indicated a significant difference (two-way ANOVA followed by Tukey's multiple comparison post hoc analysis, $p \leq 0.05)$.

We next performed high-resolution tandem mass spectrometry analyses to detect MsrA and MsrAB in the B. cereus anoxic cellular proteome. Only one peptide was assigned to each of the two Msr in this analysis (data not shown). The same analysis of an oxic cellular proteome detected two and five peptides for MsrA and MsrAB, respectively [27]. No Msr-peptide was detected in B. cereus exoproteome whatever the oxygenation conditions, indicating that both MsrA and MsrAB are cytoplasmic proteins. These results suggest that both Msr proteins are expressed at low abundance, and that their levels are decreased when cells are grown in anaerobic conditions compared to aerobic growth conditions. 


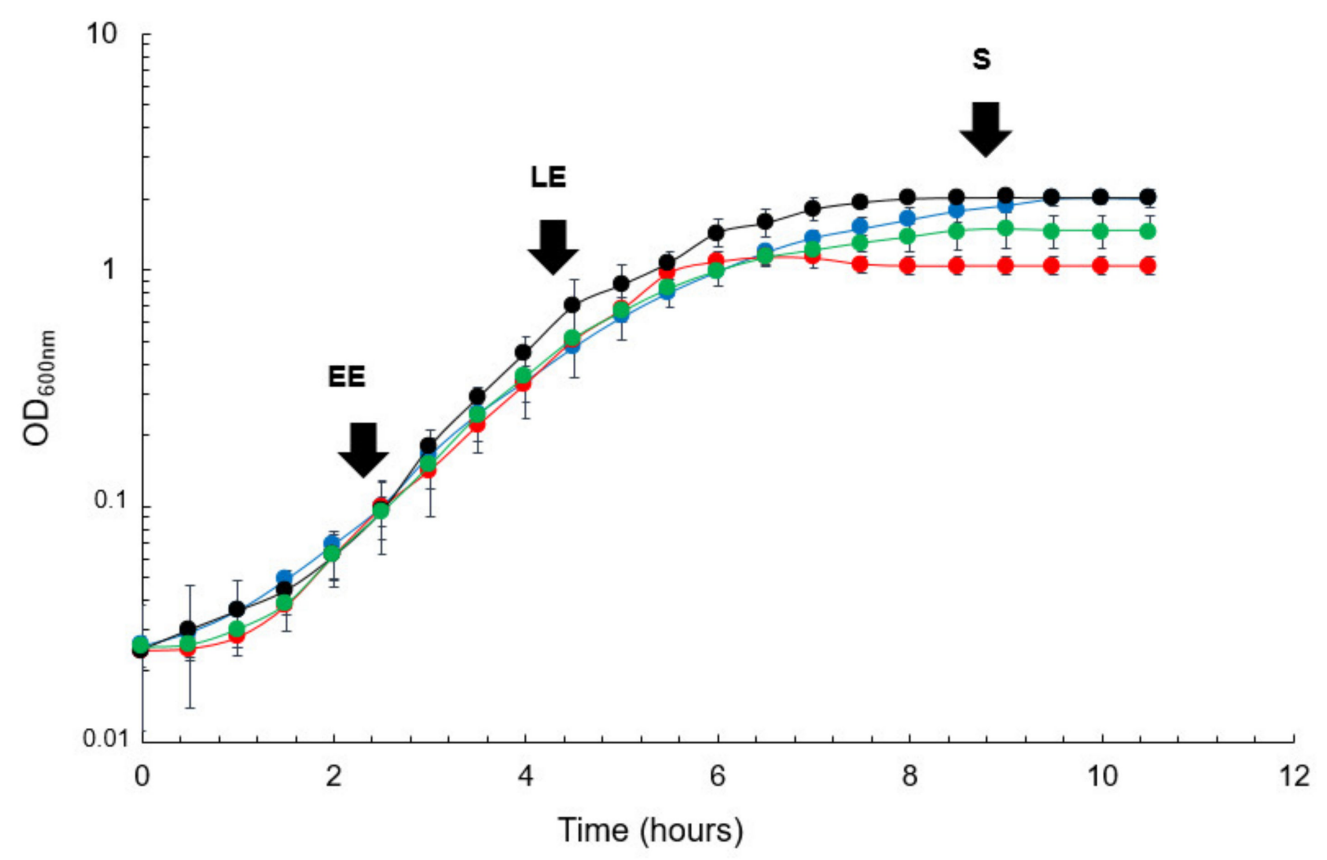

Figure 2. Growth curves for B. cereus wild-type and $m s r$ mutant strains under anaerobic fermentative conditions. Wild-type strain ATCC 14579 (black), $\triangle m s r A$ (green), $\triangle m s r A B$ (blue), and $\triangle m s r A \Delta m s r A B$ mutants (red) were grown in MOD medium supplemented with $30 \mathrm{mM}$ glucose. Data correspond to the mean \pm SD of three biological replicates.

\subsection{Effect of msrA and msrAB Mutations on Anaerobic Fermentative Metabolism}

We previously reported the construction of a $\triangle m s r A B$ mutant strain [27]. For the present study, we disrupted the $m s r A$ gene in WT and $m s r A B$ mutant strains to create a single $\triangle m s r A$ mutant and a double $\triangle m s r A \triangle m s r A B$ mutant, respectively. Quantitative RT-PCR analyses confirmed that both mutant strains lack $m s r A$ expression. Expression was restored by complementation of these strains with a plasmid carrying the $m s r A$ gene (pHT304-msrA) (data not shown).

We first compared the growth features of the $\triangle m s r A, \triangle m s r A B$ and double $\triangle m s r A \triangle m s r A B$ mutants to those of the parental ATCC 14579 wild-type strain (Figure 2). A similar maximal specific growth rate $\left(\mu_{\max }\right)$ was measured for all four strains (Table 1$)$.

Table 1. Growth parameters and end product yields obtained for anaerobic batch cultures of $\triangle m s r A$, $\triangle m s r A B$ and $\triangle m s r A \triangle m s r A B$ mutants, and their parental strain, B. cereus ATCC 14579 (WT).

\begin{tabular}{ccccc}
\hline & \multicolumn{4}{c}{ B. cereus Strains } \\
\hline & WT & $\Delta m s r A$ & $\Delta m s r A B$ & $\Delta m s r A \Delta m s r A B$ \\
\hline$\mu_{\max }\left(\mathrm{h}^{-1}\right)$ & $1.0 \pm 0.1^{\mathrm{a}}$ & $1.0 \pm 0.1^{\mathrm{a}}$ & $0.9 \pm 0.1^{\mathrm{a}}$ & $1.0 \pm 0.1^{\mathrm{a}}$ \\
\hline Final $\mathrm{DD}_{600}$ & $2.0 \pm 0.1^{\mathrm{a}}$ & $1.4 \pm 0.2^{\mathrm{b}}$ & $2.0 \pm 0.1^{\mathrm{a}}$ & $1.1 \pm 0.1^{\mathrm{c}}$ \\
\hline Final biomass $(\mathrm{g} / \mathrm{L})$ & $0.8 \pm 0.1^{\mathrm{a}}$ & $0.6 \pm 0.1^{\mathrm{b}}$ & $0.8 \pm 0.1^{\mathrm{a}}$ & $0.4 \pm 0.1^{\mathrm{c}}$ \\
\hline $\mathrm{q}_{\text {glucose }}(\mathrm{mmol} / \mathrm{g} / \mathrm{h})$ & $77 \pm 7^{\mathrm{a}}$ & $96 \pm 4^{\mathrm{b}}$ & $103 \pm 5^{\mathrm{b}}$ & $168 \pm 5^{\mathrm{c}}$ \\
\hline $\mathrm{Y}_{\text {acetate }}(\mathrm{mol} / \mathrm{mol})$ & $0.31 \pm 0.01^{\mathrm{a}}$ & $0.41 \pm 0.01^{\mathrm{b}}$ & $0.24 \pm 0.01^{\mathrm{c}}$ & $0.65 \pm 0.04^{\mathrm{d}}$ \\
\hline $\mathrm{Y}_{\text {lactate }}(\mathrm{mol} / \mathrm{mol})$ & $1.45 \pm 0.06^{\mathrm{a}}$ & $1.52 \pm 0.01^{\mathrm{a}}$ & $1.57 \pm 0.06^{\mathrm{a}}$ & $1.47 \pm 0.42^{\mathrm{a}}$ \\
\hline $\mathrm{Y}_{\text {formate }}(\mathrm{mol} / \mathrm{mol})$ & $0.39 \pm 0.08^{\mathrm{a}}$ & $0.47 \pm 0.01^{\mathrm{a}}$ & $0.31 \pm 0.08^{\mathrm{a}}$ & $0.44 \pm 0.07^{\mathrm{a}}$ \\
\hline $\mathrm{Y}_{\text {ethanol }}(\mathrm{mol} / \mathrm{mol})$ & $0.10 \pm 0.00^{\mathrm{a}}$ & $0.07 \pm 0.02^{\mathrm{a}}$ & $0.10 \pm 0.00^{\mathrm{a}}$ & $0.08 \pm 0.02^{\mathrm{a}}$ \\
\hline $\mathrm{Y}_{\text {succinate }}(\mathrm{mol} / \mathrm{mol})$ & $0.04 \pm 0.00^{\mathrm{a}}$ & $0.00 \pm 0.00^{\mathrm{b}}$ & $0.05 \pm 0.00^{\mathrm{a}}$ & $0.00 \pm 0.00^{\mathrm{b}}$ \\
\hline abc Within a row $\mathrm{means} \pm \mathrm{SD}$ withouta $^{\mathrm{b}}$ & & & & \\
\hline
\end{tabular}

abc Within a row, means \pm SD without a common superscript significantly differ (Student's $t$ test, $p \leq 0.05$ ). 
However, $\triangle m s r A \triangle m s r A B$ and $\triangle m s r A$ mutants reached the stationary growth phase at a lower final biomass than the $\triangle m s r A B$ mutant and WT strains (1.3 and 2-fold decrease, respectively, Figure 2, Table 1). Interestingly, the final biomass recorded for the $\triangle m s r A$ mutant was significantly higher than that for the $\triangle m s r A \Delta m s r A B$ double mutant. The highest specific glucose uptake rate (qglucose) was measured for the $\triangle m s r A \Delta m s r A B$ double mutant, indicating that glucose supports higher glycolytic fluxes in the absence of Msr. As with the WT strain, glucose was mainly metabolized into lactate by mutant strains, and no difference in terms of lactate secretion yield was observed (Table 1). However, the $\triangle m s r A$ and $\triangle m s r A \triangle m s r A B$ mutants produced more acetate and smaller amounts of succinate than the $\triangle m s r A B$ mutant and WT strains. The $\triangle m s r A \triangle m s r A B$ double mutant accumulated higher levels of acetate in the growth medium than the $\triangle m s r A$ single mutant. Taken together, these data suggest that MsrA mediates a much more significant regulatory effect on fermentative metabolism than MsrAB, and that, together, the two proteins may contribute to the regulation of carbon flow at the pyruvate node.

\subsection{Met (O) Accumulation in msr Mutant Proteomes}

Since the lack of Msr activity makes cellular proteome and exoproteome more susceptible to oxidation [27], we compared the total Met(O) peptide content of cellular (Table S1) and extracellular (Table S2) protein samples harvested at EE, LE and S growth phase from cultures of $m s r$ mutants and WT strains (Figure 2). The Met(O) peptide content was estimated as a percentage of the total number of peptides identified in each of the three biological replicates obtained from each growth phase. The data showed no significant changes in intracellular $\operatorname{Met}(\mathrm{O})$ peptide content as growth progressed for any strain (Figure 3a). However, higher Met(O) levels were detected in $\triangle m s r A$ and $\triangle m s r A \Delta m s r A B$ mutant strains compared to $\triangle m s r A B$ mutant and WT strains regardless of the growth phase, and in the $\triangle m s r \triangle A m s r A B$ double mutant compared to the $m s r A$ single mutant at the EE and LE growth phases. Met $(\mathrm{O})$ peptide content accounted for $8 \%$ of all peptides expressed by the $\triangle m s r A \Delta m s r A B$ mutant at the beginning of the exponential growth phase (EE). No significant differences in extracellular $\operatorname{Met}(\mathrm{O})$ were found between the mutant and the parental strains (Figure $3 \mathrm{~b}$ ). $\operatorname{Met}(\mathrm{O})$ accounted for up to $13 \%$ of the total extracellular peptide count. Taken together, these data show that MsrA is a major contributor to the regulation of cellular proteomewide methionine oxidation under anaerobiosis, whereas MsrAB appears to play a minor role in this process.

\subsection{Identification of Putative Msr Substrates}

Proteins carrying MetO residues that are differentially oxidized in $m s r$ mutants are likely to be substrates for Msr. To identify Msr substrates, we considered that a peptide contained $\operatorname{Met}(\mathrm{O})$ residues $(\mathrm{Met}(\mathrm{O})$ peptide) when the oxidized form was detected in a least two biological replicates at different time-points. On this basis, we identified $476 \mathrm{Met}(\mathrm{O})$ peptides in cellular extracts (Table S1) and $370 \operatorname{Met}(\mathrm{O})$ peptides in extracellular extracts (Table S2). We then examined changes in $\operatorname{Met}(\mathrm{O})$ levels in these peptides. Only peptides for which the $\operatorname{Met}(\mathrm{O})$ content changed more than 1.5-fold in at least one mutant strain compared to WT (adjusted $p$-value < 0.05) were selected. Based on this criterion, $43 \mathrm{Met}(\mathrm{O})$-peptides from 15 proteins were confidently identified from cellular extracts (Table 2), and $35 \mathrm{Met}(\mathrm{O}$ )peptides from 21 proteins were identified from extracellular extracts (Table 3). To exclude any influence of bias in protein abundance on the observed differences in levels of $\operatorname{Met}(\mathrm{O})$, we performed, in parallel, a differential proteomics analysis on the 998 cellular proteins and 433 exoproteins validated by at least two peptides (Tables S3 and S4). The statistical criteria applied were the same as those used to determine the $\operatorname{Met}(\mathrm{O})$ level. This analysis revealed 43 cellular proteins (Table S5) and 41 extracellular proteins (Table S6) for which significant abundance changes were detected. Two cellular proteins, the glycolytic enzyme glucose 6-phosphate isomerase and the protein Gls24, were found to be increased both in terms of their $\operatorname{Met}(\mathrm{O})$ content (Table 2) and their abundance in $\triangle m s r A$ and $\triangle m s r A \Delta m s r A B$ mutants compared to WT (Table S5). Both the Met(O) level and overall abundance of 
four extracellular proteins were decreased in mutant strains compared to WT (Table 3 and Table S6). Among these proteins, three (flagellins FlaA, FlaB and FlaC) are components of the flagellar apparatus. Finally, out of the 15 proteins listed in Table 2, thirteen are potential substrates of Msr, whereas, out of the 21 extracellular proteins listed in Table 3, seventeen may be potential substrates of Msr.

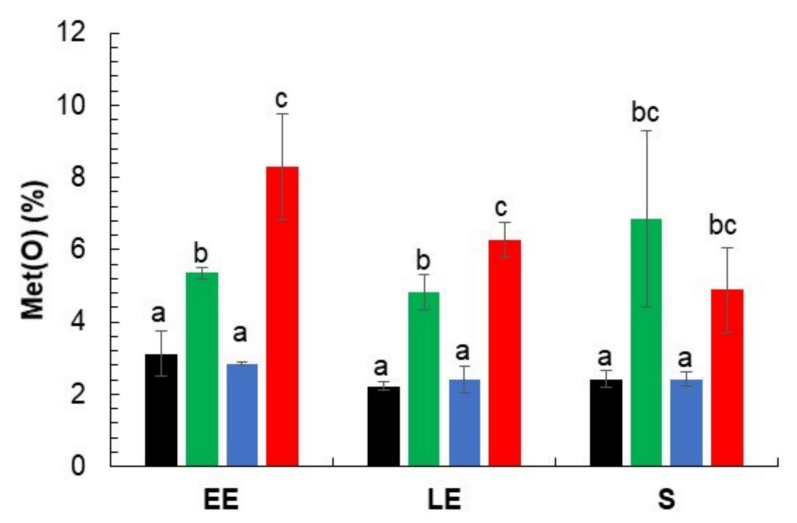

(a)

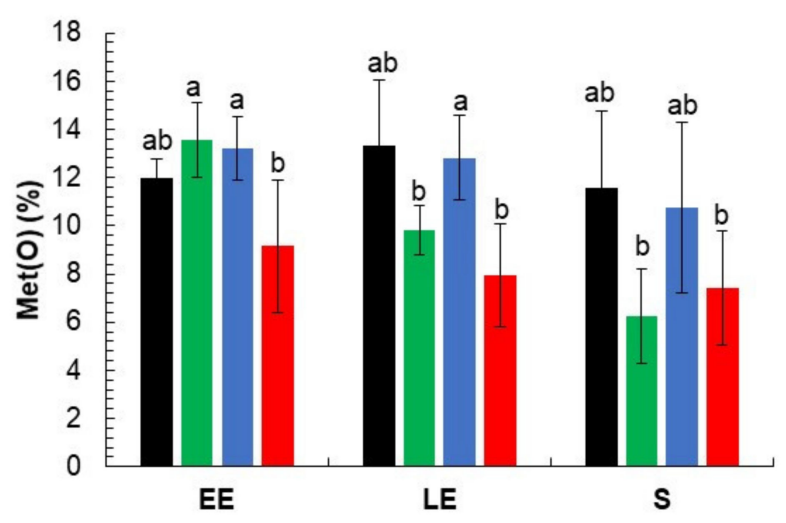

(b)

Figure 3. $\operatorname{Met}(\mathrm{O})$ content of $B$. cereus wild-type and $m s r$ mutant proteomes under anaerobic fermentative conditions. Wild-type strain ATCC 14579 (black), $\triangle m s r A$ (green), $\triangle m s r A B$ (blue), and $\triangle m s r A \triangle m s r A B$ mutants (red), were grown in MOD medium supplemented with $30 \mathrm{mM}$ glucose. Samples were collected at early exponential (EE), late exponential (LE), and stationary (S) growth phases, as indicated in Figure 2. The relative Met(O) content in the cellular proteome (a) and exoproteome (b) was calculated as a percentage of oxidized methionine-containing peptides with respect to the total number of methionine-containing peptides identified in samples for each growth phase. Data correspond to the mean \pm SD of three biological replicates. Within each panel, data denoted by a common letter are not significantly different. Data designed by different letters indicated a significant difference (two-way ANOVA followed by Tukey's multiple comparison post hoc analysis, $p \leq 0.05)$. 


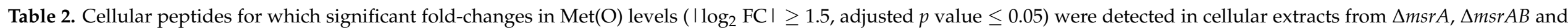
$\triangle m s r A \triangle m s r A B$ compared to WT at early exponential growth phase (EE), late exponential growth phase (LE) and stationary growth phase (S).

Molecular Function

Gene No

Met(O) Peptide Detected by LC MS/MS a

\begin{tabular}{|c|c|c|c|c|c|}
\hline \multicolumn{6}{|c|}{$\log _{2} \mathrm{FC}^{b}$} \\
\hline & & & & & S \\
\hline $\begin{array}{l}\frac{\pi}{5} \\
\frac{1}{3}\end{array}$ & 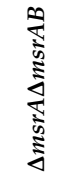 & 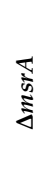 & 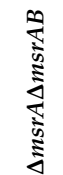 & $\begin{array}{l}\frac{\pi}{2} \\
\vdots\end{array}$ & 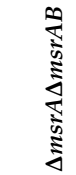 \\
\hline
\end{tabular}

\begin{tabular}{|c|c|c|c|c|c|c|c|c|c|c|c|}
\hline $\begin{array}{l}\text { Amino acid } \\
\text { metabolism }\end{array}$ & BC1238 & $\operatorname{TrpA}$ & $\begin{array}{l}\text { Tryptophan synthase, } \\
\text { alpha subunit }\end{array}$ & $1 / 5$ & EVQMPFVLMTYLNPVLAFGK & & & & & 4.2 & \\
\hline ATP synthesis & ВС5308 & AtpA & $\begin{array}{l}\text { F0F1 ATP synthase, alpha } \\
\text { subunit }\end{array}$ & $1 / 10$ & IMQVPVGK & & & 2.3 & & & \\
\hline \multirow{3}{*}{ Chaperone proteins } & \multirow{3}{*}{ ВС0295 } & \multirow{3}{*}{ GroEL } & \multirow{3}{*}{ Chaperonin } & \multirow{3}{*}{$5 / 20$} & SALQNAASVAAMFLTTEAVVADKPEPNAPAMPDMGGMGMGGMGGMM & & & & & 3.3 & \\
\hline & & & & & SSIAQVAAISAADEEVGQLIAEAMER & 3.0 & & 3.9 & 4.5 & 4.0 & \\
\hline & & & & & AMLEDIAILTGGEVITEELGR & 4.5 & 5.0 & 4.3 & 4.6 & 4.7 & 4.3 \\
\hline $\begin{array}{l}\text { Degradative } \\
\text { enzymes }\end{array}$ & BC1991 & $\operatorname{TgC}$ & $\begin{array}{l}\text { Putative murein } \\
\text { endopeptidase }\end{array}$ & $1 / 9$ & YKQSMDGTMQDIKK & & & -3.3 & & & \\
\hline \multirow{3}{*}{ Fermentation } & \multirow{2}{*}{ BC4365 } & \multirow{2}{*}{ AdhE } & \multirow{2}{*}{$\begin{array}{l}\text { bifunctional } \\
\text { acetaldehyde-CoA } \\
\text { alcohol dehydrogenase }\end{array}$} & \multirow{2}{*}{$4 / 30$} & MIDTLVNNGQQALQALESFTQEEIDNIVHEMALAGVDQHMPLAK & & & 2.6 & 3.0 & & \\
\hline & & & & & LPLISELKEIYMK & 2.8 & & 3.2 & 4.3 & & \\
\hline & BC4870 & Ldh2 & L-lactate dehydrogenase & $1 / 7$ & GIMDSGFDGIFLIATNPVDILTYVTWK & & 3.2 & & & 4.8 & 3.7 \\
\hline \multirow{12}{*}{$\begin{array}{c}\text { Glycolysis } \\
\text { Gluconeogenesis }\end{array}$} & BC4599 & PykI & Pyruvate kinase & $1 / 16$ & AASTDEMLDTAIQTGMDAGLIGLGDTVVITAGVPVAETGTTNLMK & 2.7 & & 3.4 & 4.0 & 3.8 & 3.4 \\
\hline & \multirow{2}{*}{$\mathrm{BC} 4898^{\mathrm{c}}$} & \multirow{2}{*}{ Pgi } & \multirow{2}{*}{$\begin{array}{l}\text { Glucose-6-phosphate } \\
\text { isomerase }\end{array}$} & \multirow{2}{*}{$2 / 9$} & $\begin{array}{l}\text { FSVLTPVGLLPIAVSGLNIEEMMK } \\
\end{array}$ & & & 3.1 & & & \\
\hline & & & & & FSVLTPVGLLPIAVSGLNIEEMMK & 2.9 & 3.5 & 3.9 & 4.8 & 4.3 & 4.4 \\
\hline & \multirow{4}{*}{ BC5135 } & \multirow{4}{*}{ Eno } & \multirow{4}{*}{$\begin{array}{l}\text { Phosphopyruvate } \\
\text { hydratase }\end{array}$} & \multirow{4}{*}{$5 / 11$} & QLPTPMMNIINGGSHADNNVDFQEFMILPVGAPTFK & & & 2.6 & & & \\
\hline & & & & & VNQIGTLTETFEAIEMAKR & 3.1 & & 3.0 & & & \\
\hline & & & & & LGANAILGVSMAVAHAAADFVGLPLYR & 3.5 & 3.7 & 3.3 & 3.6 & & 2.9 \\
\hline & & & & & AMIELDGTPNK & & & -2.9 & & & \\
\hline & \multirow{5}{*}{ BC5140 } & \multirow{5}{*}{ GapA2 } & \multirow{5}{*}{$\begin{array}{l}\text { Glyceraldehyde-3- } \\
\text { phosphate } \\
\text { dehydrogenase }\end{array}$} & \multirow{5}{*}{$4 / 9$} & GMMTTIHSYTNDQQILDLPHK & & & & & & 3.8 \\
\hline & & & & & GILGYSEEPLVSIDYNGCTASSTIDALSTMVMEGNMVK & & & 3.0 & & & \\
\hline & & & & & GMMTTIHSYTNDQQILDLPHKDLR & & & 3.0 & & & \\
\hline & & & & & GILGYSEEPLVSIDYNGCTASSTIDALSTMVMEGNMVK & 3.0 & & 4.1 & 4.0 & & \\
\hline & & & & & AAAENMIPTSTGAAK & -2.3 & & -2.3 & & & \\
\hline
\end{tabular}


Table 2. Cont.

Molecular Function

Gene No $\quad \begin{gathered}\text { Protein } \\ \text { Name }\end{gathered}$

Description

Met(O)/
Total Met

Met(O) Peptide Detected by LC MS/MS

\begin{tabular}{|c|c|c|c|c|c|}
\hline \multicolumn{6}{|c|}{$\log _{2} \mathrm{FC}^{b}$} \\
\hline & & & & & $S$ \\
\hline 离 & 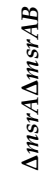 & 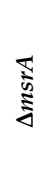 & 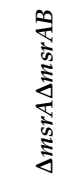 & 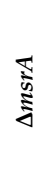 & 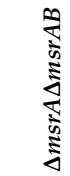 \\
\hline
\end{tabular}

Protein export

BC4410

YajC

Preprotein translocase

$1 / 6$

AVAQMQSELAK

CDMVDDEELLELVEMEVRDLLSEYGFPGDDIPVIK

ETDKPFLMPVEDVFSITGR

IIELMAEVDAYIPTPERETDKPFL MPVEDVFSITGR

IIELMAEVDAYIPTPERETDKPFLMPVEDVFSITGR

NMITGAAQMDGGILVVSAADGPMPQTR

QVGVPYIVVFLNKCDMVDDEELLELVEMEVR

\begin{tabular}{|c|c|c|c|c|c|c|c|c|c|c|}
\hline \multirow{3}{*}{$\begin{array}{l}\text { Translation } \\
\text { apparatus }\end{array}$} & \multirow{3}{*}{ ВС0129 } & \multirow{3}{*}{ Tuf } & \multirow{3}{*}{ Elongation factor Tu } & \multirow{3}{*}{$10 / 12$} & & & & & & \\
\hline & & & & & TTDVTGIIQLPEGTEMVMPGDNIEMTIELIAPIAIEEGTK & 3.1 & 3.6 & 3.9 & 4.5 & 4.3 \\
\hline & & & & & TTDVTGIIQLPEGTEMVMPGDNIEMTIELIAPIAIEEGTK & 3.1 & 3.1 & 3.4 & 3.9 & 3.4 \\
\hline & & & & & TTDVTGIIQLPEGTEMVMPGDNIEMTIELIAPIAIEEGTK & & 4.0 & 4.3 & 3.7 & 3.6 \\
\hline & & & & & TTDVTGIIQLPEGTEMVMPGDNIEMTIELIAPIAIEEGTK & & & & 3.2 & 3.3 \\
\hline & & & & & TTDVTGIIQLPEGTEMVMPGDNIEMTIELIAPIAIEEGTK & & & & & 2.9 \\
\hline & & & & & VGDVVEIIGLAEENASTTVTGVEMFR & & & & 5.1 & 4.0 \\
\hline & & & & & VGDVVEIIGLAEENASTTVTGVEMFRK & & 6.1 & 6.1 & 4.4 & \\
\hline & BC5471 & RplI & $50 \mathrm{~S}$ ribosomal protein $\mathrm{L} 9$ & $1 / 4$ & QGLAAEATNSSMK & & -5.0 & -4.6 & -4.7 & -5.6 \\
\hline & ВС0155 & Rpm & $\begin{array}{c}50 \mathrm{~S} \text { ribosomal protein } \\
\text { L36 }\end{array}$ & $1 / 2$ & VMVICENPK & & -2.9 & & & \\
\hline acategorized & BC4182 ${ }^{\mathrm{C}}$ & Gls24 & Unknown & $1 / 6$ & VEIAPEVIEVIAGIAAAEVEGVAAMR & 2.7 & 3.2 & & 3.9 & 3.2 \\
\hline
\end{tabular}

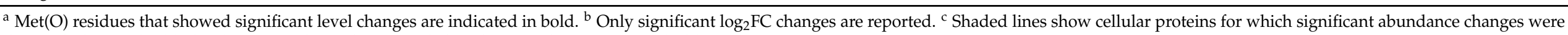
detected: the two highlighted proteins showed increased abundance in the msr mutant (Table S5). 


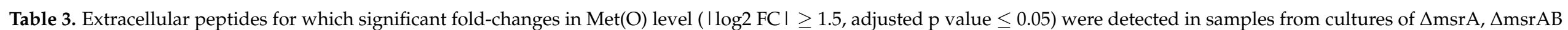
and $\Delta$ msrA $\triangle$ msrAB compared to WT at early exponential growth phase (EE), late exponential growth phase (LE) and stationary growth phase (S).

\begin{tabular}{|c|c|c|c|c|c|c|c|c|c|c|c|c|c|c|}
\hline \multirow[b]{3}{*}{$\begin{array}{l}\text { Molecular } \\
\text { Function }\end{array}$} & \multirow[b]{3}{*}{ Gene No } & \multirow[b]{3}{*}{$\begin{array}{l}\text { Protein } \\
\text { Name }\end{array}$} & \multirow[b]{3}{*}{ Description } & \multirow[b]{3}{*}{$\begin{array}{l}\text { Met(O)/ } \\
\text { Total Met }\end{array}$} & \multirow[b]{3}{*}{ Met(O) Peptide Detected by LC MS/MS } & \multicolumn{9}{|c|}{$\log _{2} \mathrm{FC}^{\mathrm{b}}$} \\
\hline & & & & & & \multicolumn{3}{|c|}{$\mathrm{EE}$} & \multicolumn{3}{|c|}{ LE } & \multicolumn{3}{|c|}{ S } \\
\hline & & & & & & 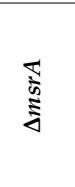 & 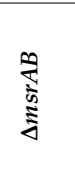 & 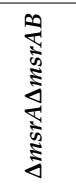 & $\begin{array}{l}\frac{\pi}{2} \\
⿱ 亠 䒑\end{array}$ & 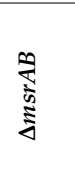 & 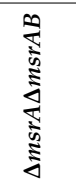 & 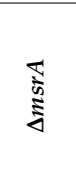 & 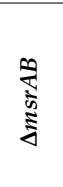 & 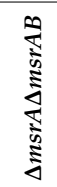 \\
\hline \multirow{2}{*}{$\begin{array}{l}\text { Cell surface } \\
\text { biogenesis }\end{array}$} & \multirow{2}{*}{ ВС5196 } & \multirow{2}{*}{ CwlD } & \multirow{2}{*}{$\begin{array}{l}\mathrm{N} \text {-acetylmuramoylL-alanine } \\
\text { amidase }\end{array}$} & \multirow{2}{*}{$3 / 8$} & MDTVVTSMTSTEGQLKELEK & -1.1 & -1.1 & -1.0 & & & & & & \\
\hline & & & & & ILESDEDIMK & -0.4 & -1.5 & -0.7 & & & & & & \\
\hline Chaperone & ВС0295 & GroEL & Chaperonin & $1 / 20$ & AMLEDIAILTGGEVITEELGR & 0.8 & 1.5 & 0.2 & & & & & & \\
\hline \multirow{10}{*}{$\begin{array}{l}\text { Degradative } \\
\text { enzymes }\end{array}$} & \multirow{2}{*}{ ВС0556 } & \multirow{2}{*}{ ColG } & \multirow{2}{*}{ Collagenase } & \multirow{2}{*}{$1 / 6$} & GLEVVTQAMHMYPR & 1.1 & 1.1 & 1.3 & & & & & & \\
\hline & & & & & MKGQAIYDIMQGIDYDIQSYLTEAR & 0.0 & 0.0 & 0.0 & 9.4 & 1.2 & 9.9 & & & \\
\hline & ВС0670 & PlcB & Phospholipase C & $1 / 6$ & AEVTPMTGKR & 2.3 & -0.1 & 2.4 & 9.5 & 2.6 & 10.0 & & & \\
\hline & BC1193 & PepF1 & Oligoendopeptidase F & $1 / 11$ & ALGLDELHMYDLYTPLVPEVK & & & & & & & 23.0 & 15.0 & 18.9 \\
\hline & \multirow{2}{*}{ BC1991 } & \multirow{2}{*}{$\operatorname{TgC}$} & \multirow{2}{*}{ Murein endopeptidase } & \multirow{2}{*}{$1 / 9$} & NIMDQLYGEFNKIVDADEYVK & & & & 9.4 & -0.4 & 8.7 & & & \\
\hline & & & & & NIMDQLYGEFNKIVDADEYVKYNVASTR & -1.0 & -0.9 & -1.0 & & & & & & \\
\hline & \multirow{2}{*}{ BC2735 } & \multirow{2}{*}{ NprP2 } & \multirow{2}{*}{ Bacillolysin } & \multirow{2}{*}{$2 / 10$} & GIGEDKMFDIFYYANTDELNMTSNFK & & & & 6.5 & 1.0 & 6.6 & & & \\
\hline & & & & & GIGEDKMFDIFYYANTDELNMTSNFK & & & & 7.5 & 1.7 & 7.5 & & & \\
\hline & \multirow{2}{*}{ ВС5351 } & \multirow{2}{*}{ NprB } & & $1 / 6$ & NMSDIYDYFKK & -1.5 & -1.2 & -0.4 & & & & & & \\
\hline & & & Bacillolysin & $1 / 6$ & GNGIYIYNANYADSLGGYSQAGYPGTLISSSTPNFADKEAAGAMK & 2.5 & 0.3 & 2.6 & 7.7 & 1.5 & 8.2 & & & \\
\hline & $\mathrm{BC} 1657 \mathrm{c}$ & $\mathrm{FlaA}$ & Flacollin & $2 / 15$ & ILNEAGISMLSQANQTPQMVSK & -3.1 & 0.0 & -3.1 & & & & & & \\
\hline & $\mathrm{DC} 163 \%$ & FlaA & Fiagenimt & $2 / 10$ & VQLSDASGDTMTIDSLNAK & & & & -6.0 & 0.1 & -8.9 & & & \\
\hline Flagella & BC1658 ${ }^{\mathrm{C}}$ & FlaB & Flagellin & $1 / 15$ & TNFNGNSFLDTTATPPGKDIEIQLSDASGDTMTLK & -1.7 & -0.7 & -2.4 & & & & & & \\
\hline & $\mathrm{BC} 1659^{\mathrm{C}}$ & $\mathrm{FlaC}$ & Flagellin & $1 / 15$ & LDHNLNNVTSQATNMAAAASQIEDADMAKEMSEMTK & -2.6 & -0.9 & -2.8 & & & & & & \\
\hline & BC4898 & Pgi & $\begin{array}{c}\text { Glucose-6-phosphate } \\
\text { isomerase }\end{array}$ & $1 / 9$ & FSVLTPVGLLPIAVSGLNIEEMMK & & & & 7.2 & 3.3 & 7.2 & & & \\
\hline $\begin{array}{l}\text { Glycolysis } \\
\text { Gluconeogenesis }\end{array}$ & BC5125 20 & Fno & Phosnhonuruyate bydratase & $2 / 11$ & LGANAILGVSMAVAHAAADFVGLPLYR & & & & 9.5 & 2.2 & 9.6 & & & \\
\hline & $\mathrm{BC} 5135$ & Eno & Inospnopyruvate ny aratase & $2 / 11$ & $\begin{array}{l}\text { VNQIGTLTETFEAIEMAK } \\
\end{array}$ & 1.8 & 1.6 & 1.4 & & & & & & \\
\hline
\end{tabular}


Table 3. Cont.

\begin{tabular}{|c|c|c|c|c|c|c|c|c|c|c|c|c|c|c|}
\hline \multirow[b]{3}{*}{$\begin{array}{l}\text { Molecular } \\
\text { Function }\end{array}$} & \multirow[b]{3}{*}{ Gene No } & \multirow[b]{3}{*}{$\begin{array}{l}\text { Protein } \\
\text { Name }\end{array}$} & \multirow[b]{3}{*}{ Description } & \multirow[b]{3}{*}{$\begin{array}{l}\text { Met(O)/ } \\
\text { Total Met }\end{array}$} & \multirow[b]{3}{*}{ Met(O) Peptide Detected by LC MS/MS ${ }^{a}$} & \multicolumn{9}{|c|}{$\log _{2} \mathrm{FC}^{\mathrm{b}}$} \\
\hline & & & & & & \multicolumn{3}{|c|}{$\mathrm{EE}$} & \multicolumn{3}{|c|}{ LE } & \multicolumn{3}{|c|}{$\mathrm{s}$} \\
\hline & & & & & & $\begin{array}{l}\frac{\pi}{2} \\
\stackrel{2}{3}\end{array}$ & 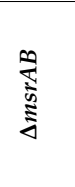 & 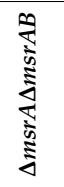 & 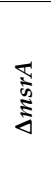 & 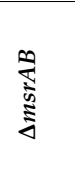 & 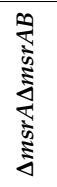 & $\begin{array}{l}\frac{\pi}{\Delta} \\
\stackrel{2}{\Delta}\end{array}$ & 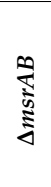 & 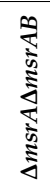 \\
\hline \multirow{13}{*}{ Exotoxins } & \multirow{2}{*}{ ВС3101 } & \multirow{2}{*}{$\mathrm{HblB}^{\prime}$} & \multirow{2}{*}{ Hemolysin BL, component $\mathrm{B}^{\prime}$} & \multirow{2}{*}{$2 / 15$} & GLDMVKIPFIPTLIAGGIMIGDAR & 1.5 & 0.9 & & & & & & & \\
\hline & & & & & IPFIPTLIAGGIMIGDAR & & & & 7.9 & 0.7 & 7.9 & & & \\
\hline & \multirow{4}{*}{ ВС3102 } & \multirow{4}{*}{$\mathrm{HblB}$} & \multirow{4}{*}{ Hemolysin BL, component B } & \multirow{4}{*}{$4 / 8$} & SMNAYSYMLIKNPDVNFEGITINGYVDLPGR & & & & 6.3 & 0.7 & 6.7 & & & \\
\hline & & & & & MKETLQK & 0.3 & -1.0 & 0.4 & & & & & & \\
\hline & & & & & QLLDTLNGIVEYDTTFDNYYETMVEAINTGDGETLKEGITDLR & & & & 8.4 & 2.2 & 7.7 & & & \\
\hline & & & & & QLLDTLNGIVEYDTTFDNYYETMVEAINTGDGETLK & & & & 7.9 & 0.9 & 7.4 & & & \\
\hline & \multirow{3}{*}{ ВС3103 } & \multirow{3}{*}{ HblL1 } & \multirow{3}{*}{ Hemolysin BL, component L1 } & \multirow{3}{*}{$3 / 8$} & MLQDFKGK & & & & 8.2 & 3.7 & 8.2 & & & \\
\hline & & & & & IGELSMKADR & 1.7 & -0.3 & 2.1 & & & & & & \\
\hline & & & & & QWNTMGANYTDLLDNIDSMEDHKFSLIPDDLK & 1.9 & 0.8 & 1.6 & 8.0 & 1.5 & 7.4 & & & \\
\hline & ВС 3523 & HlyII & Hemolysin II & $1 / 7$ & DSFNTFYGNQLFMK & & & & 0.9 & -5.4 & 0.9 & & & \\
\hline & BC1809 & NheA & Non hemolytic enterotoxin, A & $1 / 9$ & VLNNNMIQIQTNVEEGTYTDSSLLQK & & & & 7.6 & -0.3 & 8.2 & & & \\
\hline & \multirow{2}{*}{ BC5101 } & \multirow{2}{*}{ HlyI } & \multirow{2}{*}{ Cereolysin } & \multirow{2}{*}{$2 / 7$} & MTLDHYGAYVAQFDVSWDEFTFDQK & 0.8 & 1.0 & 0.4 & & & & & & \\
\hline & & & & & KVMVAAYK & & & & 6.3 & & 6.3 & & & \\
\hline Toxin-like & BC5239 & EntA & Enterotoxin, cell wall binding & $1 / 5$ & VLTAMGHDLTANPNMK & -1.4 & -1.4 & -0.6 & & & & & & \\
\hline Uncategorized & BC5027 c & & ErfK/srfK precursor & $1 / 4$ & MYNNDIHWLFER & -1.6 & -0.9 & -1.0 & & & & & & \\
\hline
\end{tabular}

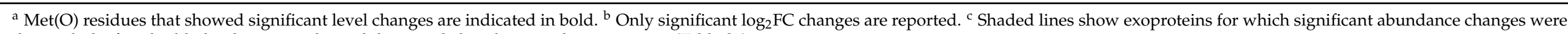
detected: the four highlighted proteins showed decreased abundance in the msr mutant (Table S6). 


\subsubsection{Putative Msr Substrates Identified in B. cereus Cellular Proteome}

According to our criteria, no significant differences in abundance for individual protein-bound $\operatorname{Met}(\mathrm{O})$ residues were found between the $\triangle m s r A B$ mutant and WT strains, regardless of the growth phase. In contrast, in $\triangle m s r A$ and/or $\triangle m s r A \Delta m s r A B$ mutants, a higher $\operatorname{Met}(\mathrm{O})$ content was detected for 32 Met residues compared to the levels present in WT (Table 2). The abundance levels for the corresponding 13 proteins were unchanged (Table S5). Interestingly, we noted that the highest number of $\operatorname{Met}(\mathrm{O})$ level changes in $\triangle m s r A$ and / or $\triangle m s r A \triangle m s r A B$ mutants was detected in samples harvested during the LE growth phase. These results indicate that MsrA has a broader substrate range than MsrAB, and that the impact of MsrAB deficiency was minor in the absence of MsrA.

The translation elongation factor Ef-Tu (Tuf)-one of the most abundant proteins in cells-contains the largest number of MsrA-Met(O) targets, representing 83\% of its total Met content. The chaperonin GroEL was also found to contain a high number of $\operatorname{Met}(\mathrm{O})$ susceptible to MsrA reduction (five residues), representing 25\% of its Met content. The Met content of glycolytic enzymes enolase (Eno) and glyceraldehyde-3-phosphate dehydrogenase (GapA2) was 45\% more oxidized in the absence of MsrA. Several other enzymes classed as involved in energy metabolism were found to be more oxidized in $\triangle m s r A$ mutant strains. These enzymes included the fermentative enzyme alcohol dehydrogenase (AdhE), the glycolytic enzyme pyruvate kinase (Pyk), the fermentative enzyme lactate dehydrogenase (Ldh2), and the alpha subunit of ATP synthase/hydrolase (AtpA). However, in contrast to Eno and GapA2, each of these enzymes contained only one MsrA-Met $(\mathrm{O})$ target, and their $\operatorname{Met}(\mathrm{O})$ residues represented no more than $14 \%$ of their total Met content. Regardless of the number of Met $(\mathrm{O})$ targets, many of these proteins corresponded to key enzymes in the energy metabolism.

\subsubsection{Putative Msr Substrates Identified in B. cereus Exoproteome}

Many of the proteins identified as putative Msr substrates in B. cereus exoproteome were typical exoproteins, including exotoxins and degradative enzymes (Table 3 ). Changes in their $\operatorname{Met}(\mathrm{O})$ content were observed mainly during the LE growth phase in all three mutant strains- $\triangle m s r A, \triangle m s r A B$ and $\triangle m s r A \triangle m s r A B$-indicating that some of their $\operatorname{Met}(\mathrm{O})$ residues can be substrates of both MsrA and MsrAB. Degradative enzymes contained no more than two Met residues for which increasing $\operatorname{Met}(\mathrm{O})$ levels were detected. Overall, exotoxins contained more $\operatorname{Met}(\mathrm{O})$ residues than other proteins. Specifically, Hbl components contained the highest number of $\operatorname{Met}(\mathrm{O})$ residues, with 37.5 and $50 \%$ of total Met residues in the lytic component HblL1 and the binding component $\mathrm{HblB}$, respectively. In conclusion, our results indicate that several virulence factors secreted by B. cereus, including toxins and degradative enzymes, are putative Msrsubstrates under anaerobiosis, particularly during the LE growth phase.

\subsection{Swimming Motility of B. cereus Depends on MsrA Activity}

Our proteomics results indicated that MsrA activity was essential to maintain the abundance level of flagellins (which drive B. cereus motility [42]). We therefore investigated swimming and swarming motility for the WT strain and compared it to that of the $\Delta m s r A$, $\triangle m s r A B$ and $\triangle m s r A \triangle m s r A B$ mutants under anaerobiosis. Data were evaluated by a Student t-test. No significant difference in cell migration capacity was observed between WT and mutant strains on media supporting swarming. In contrast, as shown in Figure 4, the $\triangle m s r A$ and the $\triangle m s r A \triangle m s r A B$ mutants gave rise to significantly smaller colonies (diameter $5.0 \pm 0.0 \mathrm{~mm}$ ) than those produced by the WT and $\triangle m s r A B$ mutant strains (diameters 10.7 \pm 0.6 and $10.3 \pm 0.6 \mathrm{~mm}$, respectively; $p$-value $<0.01)$. This reduced diameter suggests that $B$. cereus swimming motility was significantly reduced in the absence of MsrA. 


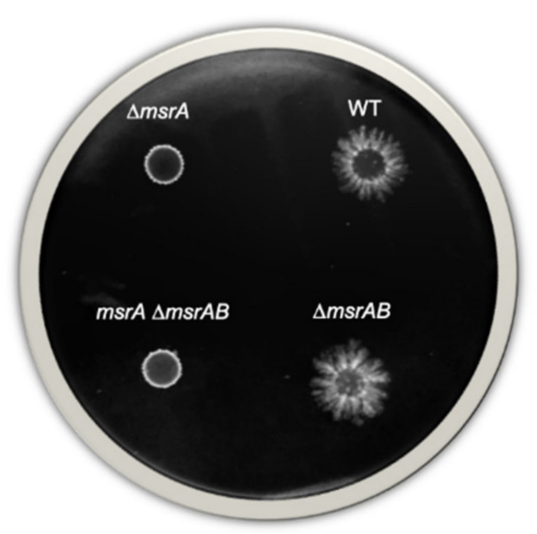

Figure 4. Swimming motility. Representative colonies of wild-type (WT) and $\triangle m s r A, \triangle m s r A B$ and $\triangle m s r A \triangle m s r A B$ mutants following growth on swimming TrA plates for $72 \mathrm{~h}$ under anaerobiosis.

\section{Discussion}

The aim of this study was to investigate the antioxidant role of Msr proteins under anaerobic fermentative growth conditions by a proteomics approach. MsrA and MsrAB are two methionine sulfoxide reductases predicted to reverse oxidative damage to methionine in B. cereus. The genes encoding these two Msr are transcribed independently, and our results show that they share similar expression patterns over the course of fermentative anaerobic growth. Thus, expression of $m s r$ genes is growth-phase dependent and reached its maximum during the LE growth phase under anaerobiosis; under aerobiosis, this maximum was reached during the stationary phase [27]. This expression profile suggests that Msr are required earlier when cells are grown under anaerobiosis compared to under oxic conditions, perhaps as a means to repair accumulated oxidative damage [43]. The contributions of MsrA and MsrAB to the reduction of cellular Met(O)-bound proteins were clearly distinct under fermentative anaerobic conditions. The extended substrate range of MsrA compared to MsrAB could explain the major role played by MsrA compared to MsrAB in B. cereus fermentative growth.

In contrast to MsrAB, a lack of MsrA significantly changed the oxidation status of Met residues in several cellular proteins including the GroEL chaperone, the elongation factor Ef-Tu, the alpha component of the F1F0-ATPase complex and key enzymes involved in central metabolic processes, which led to concomitant changes in the distribution of metabolic fluxes (Figure 5).

GroEL is a Met-rich chaperone that functions in vivo to fold newly synthetized peptides. The chaperonin activity of GroEL needs ATP [44] and, in Escherichia coli, depends on a Msr-mediated repair system under oxic growth conditions [45]. In Helicobacter pylori, the Msr-mediated repair of GroEL serves to protect catalase against oxidative damage [46]. The elongation factor Ef-Tu is a translational GTPase that plays a central role during the elongation phase of protein synthesis in bacteria and eukaryotes. It also displays diverse moonlighting functions related to bacterial pathogenesis [47]. In eukaryotes, Msr-based repair systems preserve the activity of Ef-Tu and other complexes to maintain protein biogenesis [16,17]. Under fermentative conditions and in the absence of oxidative phosphorylation, the F0F1 ATPase complex hydrolyzes ATP and plays a key role in the $\mathrm{H}^{+}$ transport accompanying certain secondary transporters and/or enzymes involved in anaerobic oxidation-reduction [48]. Impairment of F0F1 as a result of enhanced Met oxidation of one of its components could increase its turnover and ATP requirements, leading to perturbed fermentative metabolism (Table 1). Changes to the oxidation status of glycolytic enzymes and fermentative enzymes, and thus in their activities [49], could also contribute to perturbing fermentative metabolism. The lactate pathway is the main fermentative pathway regenerating $\mathrm{NAD}^{+}$from $\mathrm{NADH}$ in $B$. cereus [2]. Indeed, during pyruvate oxidation, $B$. cereus produces significantly more lactate than succinate and ethanol (Table 1). Lactate and ethanol production were unchanged in the absence of MsrA, whereas succinate formation 
was decreased. However, due to the minor impact of the succinate pathway on $\mathrm{NAD}^{+}$ generation, this decrease probably has a neutral effect on the cellular redox balance. The acetate pathway does not involve redox reactions and generates additional ATP outside of glycolysis through the conversion of acetyl-CoA to acetate (Figure 5). In the absence of MsrA, acetate secretion is increased, indicating a higher carbon flow through acetate pathway, and a concomitantly higher ATP production. To sustain high carbon flow through the acetate pathway, $\triangle m s r A$ and $\triangle m s r A \triangle m s r A B$ mutants increase carbon flow through glycolysis, as revealed by increased glucose consumption (Table 1). Finally, when MsrA is lacking, B. cereus adjusts its fermentative metabolism to maintain redox balance and promote ATP synthesis, probably to sustain — for as long as possible-repairing processes that have become less efficient due to the absence of Msr, and F0F1 ATPase complex deficiency.

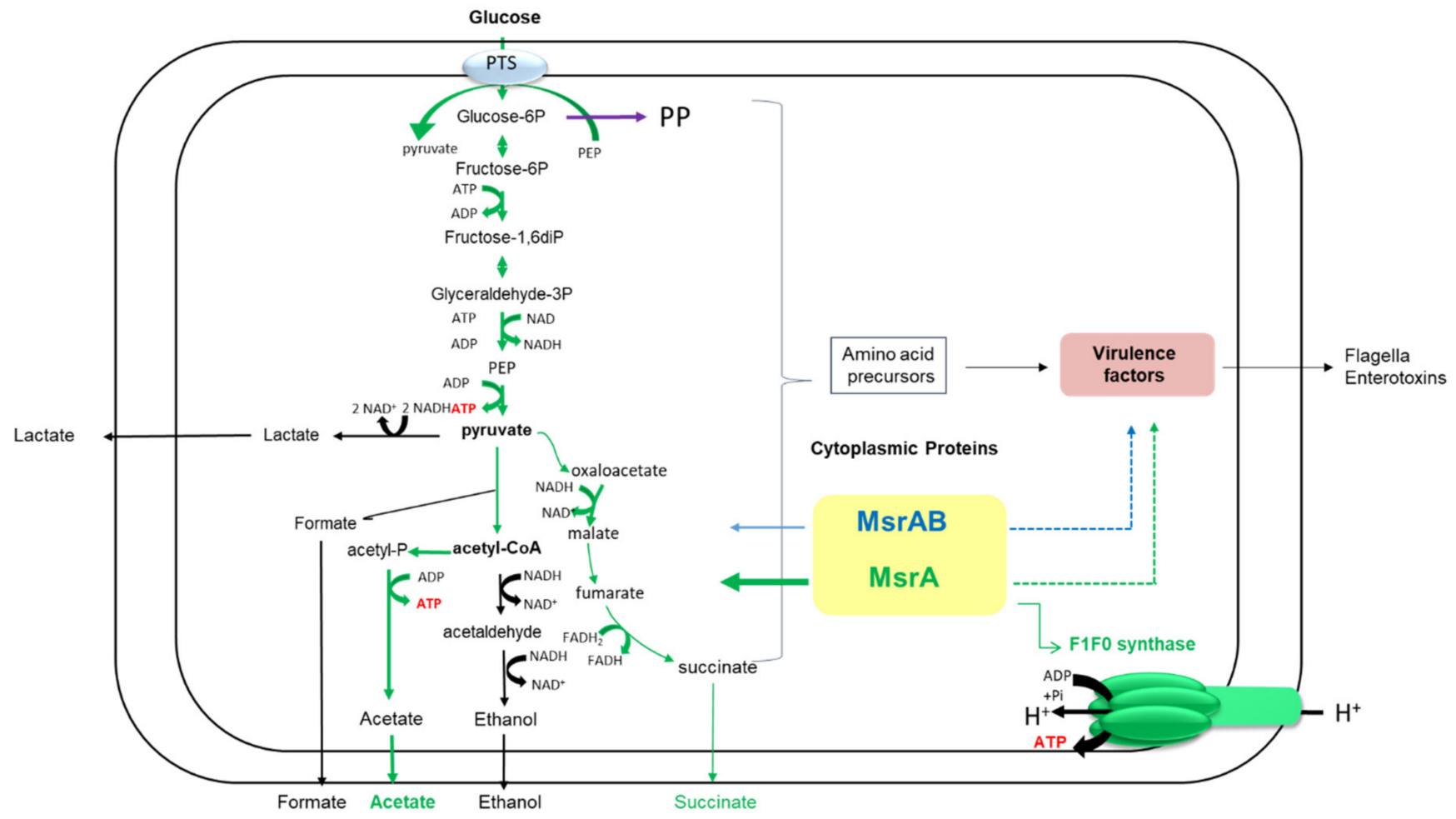

Figure 5. Schematic view of the roles of MsrA and MsrAB on B. cereus physiology under anaerobic fermentative conditions. MsrA has a more important role in fermentative metabolism, compared to MsrAB (thick green vs. thin blue solid arrows). The role of MsrA could be as important as the role of MsrAB in maintaining Met(O) levels of virulence factors, such as flagella and enterotoxins (green and blue dotted arrows). PTS, phosphotransferase system; PP, pentose phosphate pathway. Succinate is formed via the reductive TCA cycle.

In terms of capacity to colonize an environment, in the absence of MsrA, B. cereus cells showed reduced motility. This result appears logical as the bacterial flagellum is responsible for motility [50], and synthesis of some flagellar components was observed to be reduced in the absence of MsrA, possibly as a result of an overoxidation of their Met residues [51]. Down-regulation of flagellar components in a context where ATP demand is increased may help cells to maintain growth. The flagellum is a potential virulence factor along the same lines as degradative enzymes and exotoxins. All these virulence factors contain several Met $(\mathrm{O})$, are highly produced at the end of growth [52], and are exported in an unfolded form [53]. Msr are known to preferentially reduce unfolded oxidized proteins [17], suggesting that these virulence factors, especially enterotoxin $\mathrm{Hbl}$, could be repaired by cytoplasmic Msr before their secretion. Whether Msr-dependent Met oxidation regulates exotoxin secretion, structure and activity remains an open question. However, as 
reported for other pathogens [54], it is probable that Msr contributes to B. cereus virulence under both anaerobiosis and aerobiosis [27].

In contrast to MsrA, a lack of MsrAB had little effect on B. cereus fermentative metabolism. Although it has a minor impact compared to MsrA, the role of MsrAB is, nevertheless, important as it contributes to the intracellular accumulation of $\operatorname{Met}(\mathrm{O})$ (Figure 3), and to fermentative metabolism in the absence of MsrA. This observation suggests that MsrA could have a higher affinity than MsrAB for surface-accessible Met $(\mathrm{O})$ within cellular proteins, and that MsrA and MsrAB could cooperate to reduce $\operatorname{Met}(\mathrm{O})$ in some proteins. Differences in $\operatorname{Met}(\mathrm{O})$ reduction activity between MsrAB and MsrA were less marked when examining extracellular proteins, suggesting that the affinity differences between the two enzymes could be less significant when dealing with unfolded proteins.

\section{Conclusions}

Even though MsrA and MsrAB seem to be present at very low levels in anaerobic fermentative $B$. cereus cells, they are part of a highly regulated machinery controlling energy metabolism and, possibly, virulence (Figure 5). In addition, our study indicates that the oxidation of methionine residues in proteins may be an inevitable side effect of life, whether under anaerobic or aerobic conditions.

Supplementary Materials: The following are available online at https://www.mdpi.com/article/10 .3390 /antiox10050819/s1, Figure S1: Analysis of $m s r A$ expression under aerobiosis, Table S1: Peptides containing oxidized methionine identified in the cellular proteomes of the B. cereus $\triangle m s r A, \triangle m s r A B$, $\triangle m s r A \triangle m s r A B$ and wild-type (WT) strains, Table S2: Peptides containing oxidized methionine identified in the exoproteomes of the B. cereus $\triangle m s r A, \triangle m s r A B, \triangle m s r A \triangle m s r A B$ and wild-type (WT) strains, Table S3: Proteins identified in the cellular proteome of the B. cereus $\triangle m s r A, \triangle m s r A B, \triangle m s r A \Delta m s r A B$ and wild-type (WT) strains, Table S4: Proteins identified in the exoproteome of the B. cereus $\triangle m s r A$, $\triangle m s r A B, \triangle m s r A \triangle m s r A B$ and wild-type (WT) strains, Table S5: Cellular proteins showing differential accumulation between $\triangle m s r A, \triangle m s r A B$ or $\triangle m s r A \triangle m s r A B$ with respect to wild-type (WT), Table S6: Extracellular proteins showing differential accumulation between $\triangle m s r A, \triangle m s r A B$ or $\triangle m s r A \triangle m s r A B$ with respect to wild-type (WT).

Author Contributions: Conceptualization, C.D.; methodology, J.-P.M., M.F., B.A.-B. and C.D.; validation, C.D., B.A.-B. and J.A.; formal analysis, B.A.-B. and C.D.; writing-original draft preparation, C.D.; writing-review and editing, C.D., B.A.-B. and J.A.; All authors have read and agreed to the published version of the manuscript.

Funding: This research received no external funding.

Institutional Review Board Statement: Not applicable.

Informed Consent Statement: Not applicable.

Data Availability Statement: The data presented in this study are openly available in the PRIDE partner repository under dataset identifiers PXD024888 for the cellular proteome of B. cereus ATCC 14579, PXD024927 for the cellular proteome of the $\triangle m s r A B$ mutant, PXD024850 for the cellular proteome of $\triangle m s r A$ mutant, PXD024849 for the cellular proteome of $\triangle m s r A B \triangle m s r A$ mutant, PXD024702 for the exoproteome of B. cereus ATCC 14579, PXD024714 for the exoproteome of $\triangle m s r A B$ mutant, PXD024847 for the exoproteome of $\triangle m s r A$ mutant and PXD024848 for the exoproteome of the $\triangle m s r A B \Delta m s r A$ mutant.

Acknowledgments: We thank Soria Benhaddi for the very efficient technical help provided.

Conflicts of Interest: The authors declare no conflict of interest.

\section{References}

1. Duport, C.; Jobin, M.; Schmitt, P. Adaptation in Bacillus cereus: From stress to disease. Front. Microbiol. 2016, 7, 1550. [CrossRef]

2. Laouami, S.; Messaoudi, K.; Alberto, F.; Clavel, T.; Duport, C. Lactate dehydrogenase A promotes communication between carbohydrate catabolism and virulence in Bacillus cereus. J. Bacteriol. 2011, 193, 1757-1766. [CrossRef]

3. Rosenfeld, E.; Duport, C.; Zigha, A.; Schmitt, P. Characterization of aerobic and anaerobic vegetative growth of the food-borne pathogen Bacillus cereus F4430/73 strain. Can. J. Microbiol. 2005, 51, 149-158. [CrossRef] 
4. Zigha, A.; Rosenfeld, E.; Schmitt, P.; Duport, C. Anaerobic cells of Bacillus cereus F4430/73 respond to low oxidoreduction potential by metabolic readjustments and activation of enterotoxin expression. Arch. Microbiol. 2006, 185, 222-233. [CrossRef] [PubMed]

5. Clair, G.; Armengaud, J.; Duport, C. Restricting fermentative potential by proteome remodeling: An adaptive strategy evidenced in Bacillus cereus. Mol. Cell Proteom. 2012, 11, M111-013102. [CrossRef] [PubMed]

6. Madeira, J.P.; Alpha-Bazin, B.; Armengaud, J.; Duport, C. Time dynamics of the Bacillus cereus exoproteome are shaped by cellular oxidation. Front. Microbiol. 2015, 6, 342. [CrossRef] [PubMed]

7. Mols, M.; Abee, T. Primary and secondary oxidative stress in Bacillus. Environ. Microbiol. 2011, 13, 1387-1394. [CrossRef] [PubMed]

8. Mols, M.; van Kranenburg, R.; van Melis, C.C.; Moezelaar, R.; Abee, T. Analysis of acid-stressed Bacillus cereus reveals a major oxidative response and inactivation-associated radical formation. Environ. Microbiol. 2010, 12, 873-885. [CrossRef] [PubMed]

9. Montgomery, H.J.; Dupont, A.L.; Leivo, H.E.; Guillemette, J.G. Cloning, expression, and purification of a nitric oxide synthase-like protein from Bacillus cereus. Biochem. Res. Int. 2010, 2010, 489892. [CrossRef]

10. Popova, T.G.; Teunis, A.; Vaseghi, H.; Zhou, W.; Espina, V.; Liotta, L.A.; Popov, S.G. Nitric oxide as a regulator of B. anthracis pathogenicity. Front. Microbiol. 2015, 6, 921. [CrossRef]

11. Luo, S.; Levine, R.L. Methionine in proteins defends against oxidative stress. FASEB J. Off. Publ. Fed. Am. Soc. Exp. Biol. 2009, 23, 464-472. [CrossRef]

12. Achilli, C.; Ciana, A.; Minetti, G. The discovery of methionine sulfoxide reductase enzymes: An historical account and future perspectives. BioFactors 2015, 41, 135-152. [CrossRef]

13. Tarrago, L.; Grosse, S.; Lemaire, D.; Faure, L.; Tribout, M.; Siponen, M.I.; Kojadinovic-Sirinelli, M.; Pignol, D.; Arnoux, P.; Sabaty, M. Reduction of protein bound methionine sulfoxide by a periplasmic dimethyl sulfoxide reductase. Antioxidants 2020, 9, 616. [CrossRef]

14. Brot, N.; Weissbach, L.; Werth, J.; Weissbach, H. Enzymatic reduction of protein-bound methionine sulfoxide. Proc. Natl. Acad. Sci. USA 1981, 78, 2155-2158. [CrossRef]

15. Grimaud, R.; Ezraty, B.; Mitchell, J.K.; Lafitte, D.; Briand, C.; Derrick, P.J.; Barras, F. Repair of oxidized proteins. Identification of a new methionine sulfoxide reductase. J. Biol. Chem. 2001, 276, 48915-48920. [CrossRef]

16. Tarrago, L.; Grosse, S.; Siponen, M.I.; Lemaire, D.; Alonso, B.; Miotello, G.; Armengaud, J.; Arnoux, P.; Pignol, D.; Sabaty, M. Rhodobacter sphaeroides methionine sulfoxide reductase P reduces R- and S-diastereomers of methionine sulfoxide from a broad-spectrum of protein substrates. Biochem. J. 2018, 475, 3779-3795. [CrossRef]

17. Tarrago, L.; Kaya, A.; Weerapana, E.; Marino, S.M.; Gladyshev, V.N. Methionine sulfoxide reductases preferentially reduce unfolded oxidized proteins and protect cells from oxidative protein unfolding. J. Biol. Chem. 2012, 287, 24448-24459. [CrossRef]

18. Laugier, E.; Tarrago, L.; Vieira Dos Santos, C.; Eymery, F.; Havaux, M.; Rey, P. Arabidopsis thaliana plastidial methionine sulfoxide reductases B, MSRBs, account for most leaf peptide MSR activity and are essential for growth under environmental constraints through a role in the preservation of photosystem antennae. Plant J. Cell Mol. Biol. 2010, 61, 271-282. [CrossRef]

19. Lourenco Dos Santos, S.; Petropoulos, I.; Friguet, B. The oxidized protein repair enzymes methionine sulfoxide reductases and their roles in protecting against oxidative stress, in ageing and in regulating protein function. Antioxidants 2018, 7, 191. [CrossRef]

20. Salmon, A.B.; Perez, V.I.; Bokov, A.; Jernigan, A.; Kim, G.; Zhao, H.; Levine, R.L.; Richardson, A. Lack of methionine sulfoxide reductase A in mice increases sensitivity to oxidative stress but does not diminish life span. FASEB J. Off. Publ. Fed. Am. Soc. Exp. Biol. 2009, 23, 3601-3608. [CrossRef]

21. Cui, Z.J.; Han, Z.Q.; Li, Z.Y. Modulating protein activity and cellular function by methionine residue oxidation. Amino Acids 2012, 43, 505-517. [CrossRef] [PubMed]

22. Slesak, I.; Slesak, H.; Zimak-Piekarczyk, P.; Rozpadek, P. Enzymatic antioxidant systems in early anaerobes: Theoretical considerations. Astrobiology 2016, 16, 348-358. [CrossRef] [PubMed]

23. Zhang, X.H.; Weissbach, H. Origin and evolution of the protein-repairing enzymes methionine sulphoxide reductases. Biol. Rev. Camb. Philos. Soc. 2008, 83, 249-257. [CrossRef] [PubMed]

24. Koc, A.; Gasch, A.P.; Rutherford, J.C.; Kim, H.Y.; Gladyshev, V.N. Methionine sulfoxide reductase regulation of yeast lifespan reveals reactive oxygen species-dependent and -independent components of aging. Proc. Natl. Acad. Sci. USA 2004, 101, 7999-8004. [CrossRef]

25. Kim, H.Y.; Zhang, Y.; Lee, B.C.; Kim, J.R.; Gladyshev, V.N. The selenoproteome of Clostridium sp. OhILAs: Characterization of anaerobic bacterial selenoprotein methionine sulfoxide reductase A. Proteins 2009, 74, 1008-1017. [CrossRef]

26. Delaye, L.; Becerra, A.; Orgel, L.; Lazcano, A. Molecular evolution of peptide methionine sulfoxide reductases (MsrA and MsrB): On the early development of a mechanism that protects against oxidative damage. J. Mol. Evol. 2007, 64, 15-32. [CrossRef]

27. Madeira, J.P.; Alpha-Bazin, B.M.; Armengaud, J.; Duport, C. Methionine residues in exoproteins and their recycling by methionine sulfoxide reductase ab serve as an antioxidant strategy in Bacillus cereus. Front. Microbiol. 2017, 8, 1342. [CrossRef]

28. Madeira, J.P.; Omer, H.; Alpha-Bazin, B.; Armengaud, J.; Duport, C. Deciphering the interactions between the Bacillus cereus linear plasmid, pBClin15, and its host by high-throughput comparative proteomics. J. Proteom. 2016, 146, 25-33. [CrossRef]

29. Zwietering, M.; Jongenburger, I.; Rombouts, F.; Van't Riet, K. Modeling of the bacterial growth curve. Appl. Environ. Microbiol. 1990, 56, 1875-1881. [CrossRef] 
30. Madeira, J.P.; Alpha-Bazin, B.; Armengaud, J.; Duport, C. Time-course proteomics dataset to monitor protein-bound methionine oxidation in Bacillus cereus ATCC 14579. Data Brief 2018, 18, 394-398. [CrossRef]

31. Murphy, E. Nucleotide sequence of a spectinomycin adenyltransferase AAD(9) determinant from Staphylococcus aureus and its relationship to AAD(3") (9). Mol. Gen. Genet. MGG 1985, 200, 33-39. [CrossRef]

32. Arnaud, M.; Chastanet, A.; Debarbouille, M. New vector for efficient allelic replacement in naturally nontransformable, low-GCcontent, gram-positive bacteria. Appl Environ. Microbiol. 2004, 70, 6887-6891. [CrossRef]

33. Guerout-Fleury, A.M.; Shazand, K.; Frandsen, N.; Stragier, P. Antibiotic-resistance cassettes for Bacillus subtilis. Gene 1995, 167, 335-336. [CrossRef]

34. Arantes, O.; Lereclus, D. Construction of cloning vectors for Bacillus thuringiensis. Gene 1991, 108, 115-119. [CrossRef]

35. Hartmann, E.M.; Allain, F.; Gaillard, J.C.; Pible, O.; Armengaud, J. Taking the shortcut for high-throughput shotgun proteomic analysis of bacteria. Methods Mol. Biol. 2014, 1197, 275-285. [CrossRef]

36. Clair, G.; Roussi, S.; Armengaud, J.; Duport, C. Expanding the known repertoire of virulence factors produced by Bacillus cereus through early secretome profiling in three redox conditions. Mol. Cell Proteom. 2010, 9, 1486-1498. [CrossRef]

37. De Groot, A.; Dulermo, R.; Ortet, P.; Blanchard, L.; Guerin, P.; Fernandez, B.; Vacherie, B.; Dossat, C.; Jolivet, E.; Siguier, P.; et al. Alliance of proteomics and genomics to unravel the specificities of Sahara bacterium Deinococcus deserti. PLoS Genet. 2009, 5, e1000434. [CrossRef]

38. Madeira, J.P.; Omer, H.; Alpha-Bazin, B.; Armengaud, J.; Duport, C. Cellular and exoproteome dynamics of Bacillus cereus ATCC 14579 with and without $\mathrm{pBClin15.} \mathrm{Data} \mathrm{Brief.} \mathrm{2016.} \mathrm{submitted.} \mathrm{[CrossRef]}$

39. Dupierris, V.; Masselon, C.; Court, M.; Kieffer-Jaquinod, S.; Bruley, C. A toolbox for validation of mass spectrometry peptides identification and generation of database: IRMa. Bioinformatics 2009, 25, 1980-1981. [CrossRef]

40. Zhang, X.; Smits, A.H.; van Tilburg, G.B.; Ovaa, H.; Huber, W.; Vermeulen, M. Proteome-wide identification of ubiquitin interactions using UbIA-MS. Nat. Protoc. 2018, 13, 530-550. [CrossRef]

41. Senesi, S.; Celandroni, F.; Salvetti, S.; Beecher, D.J.; Wong, A.C.L.; Ghelardi, E. Swarming motility in Bacillus cereus and characterization of a fliY mutant impaired in swarm cell differentiation. Microbiology 2002, 148, 1785-1794. [CrossRef] [PubMed]

42. Liu, M.M.; Coleman, S.; Wilkinson, L.; Smith, M.L.; Hoang, T.; Niyah, N.; Mukherjee, M.; Huynh, S.; Parker, C.T.; Kovac, J.; et al. Unique inducible filamentous motility identified in pathogenic Bacillus cereus group species. ISME J. 2020, 14, 2997-3010. [CrossRef]

43. Dukan, S.; Nystrom, T. Oxidative stress defense and deterioration of growth-arrested Escherichia coli cells. J. Biol. Chem. 1999, 274, 26027-26032. [CrossRef]

44. Sigler, P.B.; Xu, Z.; Rye, H.S.; Burston, S.G.; Fenton, W.A.; Horwich, A.L. Structure and function in GroEL-mediated protein folding. Ann. Rev. Biochem. 1998, 67, 581-608. [CrossRef] [PubMed]

45. Khor, H.K.; Fisher, M.T.; Schoneich, C. Potential role of methionine sulfoxide in the inactivation of the chaperone GroEL by hypochlorous acid ( $\mathrm{HOCl}$ ) and peroxynitrite (ONOO-). J. Biol. Chem. 2004, 279, 19486-19493. [CrossRef] [PubMed]

46. Mahawar, M.; Tran, V.; Sharp, J.S.; Maier, R.J. Synergistic roles of Helicobacter pylori methionine sulfoxide reductase and GroEL in repairing oxidant-damaged catalase. J. Biol. Chem. 2011, 286, 19159-19169. [CrossRef]

47. Harvey, K.L.; Jarocki, V.M.; Charles, I.G.; Djordjevic, S.P. The diverse functional roles of elongation factor Tu (EF-Tu) in microbial pathogenesis. Front. Microbiol. 2019, 10, 2351. [CrossRef] [PubMed]

48. Trchounian, A. Escherichia coli proton-translocating F0F1-ATP synthase and its association with solute secondary transporters and/or enzymes of anaerobic oxidation-reduction under fermentation. Biochem. Biophys. Res. Commun. 2004, 315, 1051-1057. [CrossRef]

49. Kaya, A.; Lee, B.C.; Gladyshev, V.N. Regulation of protein function by reversible methionine oxidation and the role of selenoprotein MsrB1. Antioxid. Redox Signal. 2015, 23, 814-822. [CrossRef] [PubMed]

50. Nakamura, S.; Minamino, T. Flagella-driven motility of bacteria. Biomolecules 2019, 9, 279. [CrossRef] [PubMed]

51. Parish, C.R.; Stanley, P. Chemical and biological properties of bacterial flagellin following iodination and oxidation by chloramineT. Immunochemistry 1972, 9, 853-872. [CrossRef]

52. Duport, C.; Rousset, L.; Alpha-Bazin, B.; Armengaud, J. Bacillus cereus decreases NHE and CLO exotoxin synthesis to maintain appropriate proteome dynamics during growth at low temperature. Toxins 2020, 12, 645. [CrossRef]

53. Senesi, S.; Ghelardi, E. Production, secretion and biological activity of Bacillus cereus enterotoxins. Toxins 2010, 2, 1690-1703. [CrossRef]

54. Singh, V.K.; Singh, K.; Baum, K. The role of methionine sulfoxide reductases in oxidative stress tolerance and virulence of Staphylococcus aureus and other bacteria. Antioxidants 2018, 7, 128. [CrossRef] 